\title{
E-Learning: The Use of Moodle
}

\author{
Vaisualua Posese-Okesene \\ Otago University, New Zealand
}

\begin{abstract}
Technology and the internet enabled e-learning which not only informs but instructs, teaches, assesses and gains feedback from others. One elearning environment that has become quite popular is Modular Object-Oriented Dynamic Learning Environment (Moodle). The objective of this project is to evaluate the use of Moodle for ",interactions" and their impact on student ",confidence", ",motivation" and „performance". Staff and students gave their perceptions on an online questionnaire drawing on their previous learning experiences. The results showed that in the context of this study, the use of Moodle to facilitate online interactions improved student-lecturer, student-student and student-content interactions. The improvement consequently made impact on students' motivation, confidence and performance. Suggested variables for e-learning included age, course design, lecturer participation and learning style.
\end{abstract}

\section{Introduction}

The movement towards electronic communication bring changes that are proposed to make enhancements to living. E-learning emerges with these electronic communications. E-learning is defined as "the appropriate application of the Internet to support the delivery of learning, skills and knowledge in a holistic approach not limited to any particular courses, technologies, or infrastructures" [1]. "History has shown that interaction is an essential component in the learning process" [2]. This research seeks to find out if the use of Moodle, a learning management system and a tool to facilitate interactions, affects online interactions and whether these interactions have any impact on student „motivation ${ }^{\text {ee }}$ and „,confidence ${ }^{\text {ee }}$ in the course and on „performance ${ }^{e e}$. Staff and studentse perceptions are the main source of information.

This research views interaction as a reciprocal communication between two or more people or between people and objects, in this study, the „course content ${ }^{\text {ee }}$. This research only uses the three types of interaction (see Figure 1) identified by Moore [3] as being student-lecturer, student-student and student-content interactions for discussion.

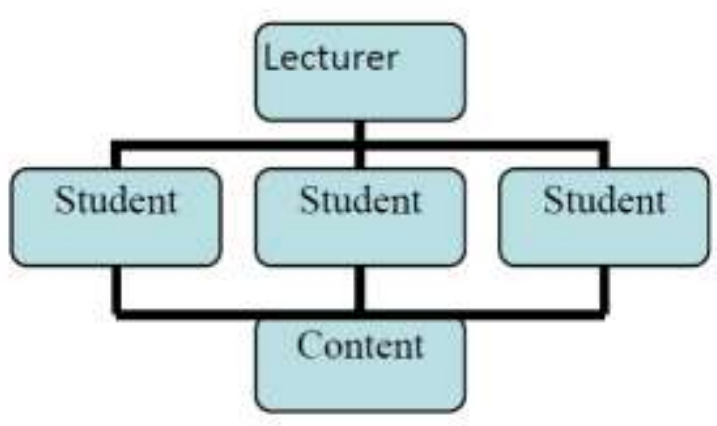

Figure 1. The three Interactions model

Student and staff perceptions are sought on Moodle's use for interactions and the impact of interactions on „motivation "e, „,confidence ${ }^{\text {ee }}$ and ,performance ${ }^{e e}$ (dependent variables). The following terminology definitions are used in the dissertation. Motivation is described by [19] as ,often examined according to 4 dimensions: choice of task, effort, persistence and achievement, where choice of task means which activity to engage, effort means the level of engagement, persistence means the time spent and willing to spend and achievement is an indirect indicator of the above 3. Confidence is generally described as a state of being certain either that a hypothesis or prediction is correct or that a chosen course of action is the best or most effective [4]. Performance is used in the context of measurement of academic progress or simply the proceedings of a learner in his or her course of learning. Performance is not necessarily measured in marks or grades.

This study hopes to find answers to the problem, highlight patterns of interactions that occur during classes and any issues that arise. This could initiate research into how to enhance facilitations of future interactions using Moodle. The current dissertation hopes to contribute to the literature by filling a gap that exists. Hardly any research has been done on the evaluations of interactions and their effects on student learning using the Moodle environment. One goal of this research is to increase the awareness on Moodle usage at Otago University especially for individuals and groups that have not yet implemented e-learning systems in their teaching.

The research is limited to the Moodle platform. The target group for the survey are adults who are 
either learners or lecturers for 4th year distant learning courses at the University of Otago College of Education (UOCE). It is assumed that the prospective participants are willing to participate in the survey. Assumptions are that the technology required in the Moodle learning environment is available and the subjects have the skills and knowledge to use this technology. Assumptions are that the subjects have no impairment of any sort and that culture and native language have no importance in this specific project.

The confounding variables are class size, lecturer ability, student ability and course type. (optional papers can be more motivating since it is the student's choice). Independent variables are;

- The courses are 4th year distant learning papers

- The time limit to submit responses was within 1 week and a few days (with reminders)

- The majority of the questions were designed to have closed answers, so that the participants just have to tick the options available.

Perhaps it can be thought that the participants were dependent variables, in the sense that the researcher had no control in their decision of whether to continue with the questionnaire.

\section{Methodology}

This study like many researches in the field of elearning used a combination of quantitative and qualitative type of methodologies. The phenomenon type of survey that mostly relies on the participants' opinions, behaviours and experiences was used [5]. Both closed questions and open questions were used in the online questionnaire.

The implementation of the survey required an Ethics approval document. The Information sheet and Consent form were put in electronic format together with the on-line questionnaire which were emailed to the prospective participants. This was the most convenient way to distribute the survey. Some reminder notices were submitted before final collection of data within one and half weeks. Most of the data analysis is descriptive. Descriptive statistics are provided to reflect the problem questions while the answers to the open questions are left in their original form for description as there are only a few.

\section{Literature Review}

\subsection{Introduction}

A large amount of research is available on the different types of e-learning technologies and infrastructures and how they contribute to education. Themes common across these researches are also analysed in the current dissertation. Some research compares e-learning platforms while other research compares e-learning to the traditional face-to-face learning, or focuses on the design mode and application. [6] and [7] researched and recommended integration of Moodle with the existing LMSs to produce enhanced systems to accommodate the organisations' needs. The integrated design heavily involved the teachers' and developers' input. [6] even included the students' input in the LMS integration for the Open University in UK. Implementation of Moodle to assist in the facilitation of e-learning was also supported by [8] for the faculty of Maritime technology in the Szczecin University of Technology.

Moodle is becoming quite popular and had a significant user base with 43,457 registered sites with 28,788,196 users in 2,844,562 courses in 204 countries, as of September, 2009 [9]. This paper reports further investigation of the appropriate application of Moodle and evaluates Moodle regarding its usage for online interactions and how it influences student motivation, confidence in the course and performance.

\subsection{The trends}

Previously, e-learning was applied mainly for distance and on-line learning but now it has become part of the mainstream learning environment in supplementing normal face-to-face on campus learning. The movement towards e-learning is not only happening in education but also in corporations, non-government organisations, small businesses, and not-for-profit organisations. "The use of e-learning education methods is currently spreading in big companies, public administration and higher education units which appreciate the importance of modern technologies in an organization development. Economic profitability of this form of training grows simultaneously with the growth of participant number", [8].

The interactions play a vital role in the effectiveness and success of online learning. Zirkin and Sumler cited in [10] stated; "The weight of evidence from the research reviewed was that increased student involvement by immediate interaction resulted in increased learning as reflected by test performance, grades, and student satisfaction". A. P. Rovai, \& K.T. Barnum [10] said research is in the vein of this dissertation in that it focussed on student perception regarding influence of course design and pedagogy on perceived learning as well as motivation and also to determine how perceptions of learning were related to course-related interactions.

A. P. Rovai, \& K.T. Barnum [10] questioned the benefits of active interaction compared to passive. The researchers concluded that passive interaction was not a significant predictor of perceived learning. They felt that the strategies and design of the courses 
appeared to have led to greater perceived learning and might have resulted in higher levels of learner satisfaction. The current study touches on the design of the course as an issue of e-learning.

Motivation is one of the themes evaluated in this dissertation. [11] concludes that; "In addition to higher performance results, there are other immediate benefits to students such as increased time on task, higher levels of motivation and reduced test anxiety for many learners". Similarly, [12] found a link that ,increased interaction" resulted in higher levels of motivation, higher academic recall and a more positive attitude towards the course. Results of a research conveyed by [13] showed that the students made a strong link between tutors frequency and quality of interaction with their enthusiasm. "Hearing from tutors on a regular basis helps to keep motivation high and keeps us as students on the right track mostly" [13]. Such inferences and conclusions were supported by [14] results which indicated that $84 \%$ of the students (survey subjects) interacted with their teachers sufficiently and analysed to strongly have related to student satisfaction and perceived learning.

On the other hand, motivation was viewed as a contributing factor to effectiveness of distance education, rather than just an outcome of interactions [15].[15] concluded that the other factors like the technology involved was "not at nearly as important as other factors, such as learning tasks, learner characteristics, student motivation and the instructor. The mention of instructor again links the importance of the teacher to the motivation of the students as inferred by Ussher's research findings [13].

\section{Results, Analysis and Discussion}

The main aim of this project was to find out if the facilitation of on-line classes using the Moodle environment influenced interactions and to evaluate if the interactions affected 1) student motivation 2) confidence in the course and 3) performance in the course. The results compared the beginning of the course and two months later. The results were used in a descriptive fashion to reveal information the respondents elicited in their answers to the survey.

\subsection{Moodle affects interactions}

The data collected suggests that most of the students felt the use of Moodle had improved all the three types of interactions. $78 \%$ students felt that the use of Moodle improved their interactions with the lecturers as well as their interactions with the course content, including $11 \%$ who said interactions with course content were improved a lot. While $67 \%$ respondents said their interactions with other students were improved, $33 \%$ did not feel the use of
Moodle had any effect, or even worse, had decreased their interactions with other students.

\subsection{Interactions affect motivation}

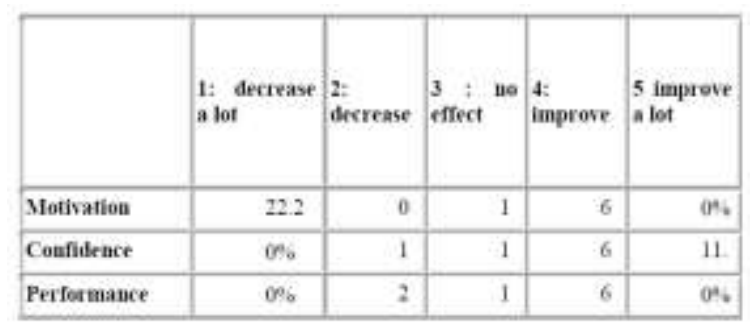

Figure 2. How interactions affected students

Figure 2 shows that, from a total of 9 respondents, $67 \%$ felt that ,interactions ${ }^{\text {ee }}$ had improved their ,motivation ${ }^{\text {ee }}$ in doing their courses while $22 \%$ felt it had decreased their motivation and about $11 \%$ thought there was no effect. The students know and can recall their experiences with the online interactions.

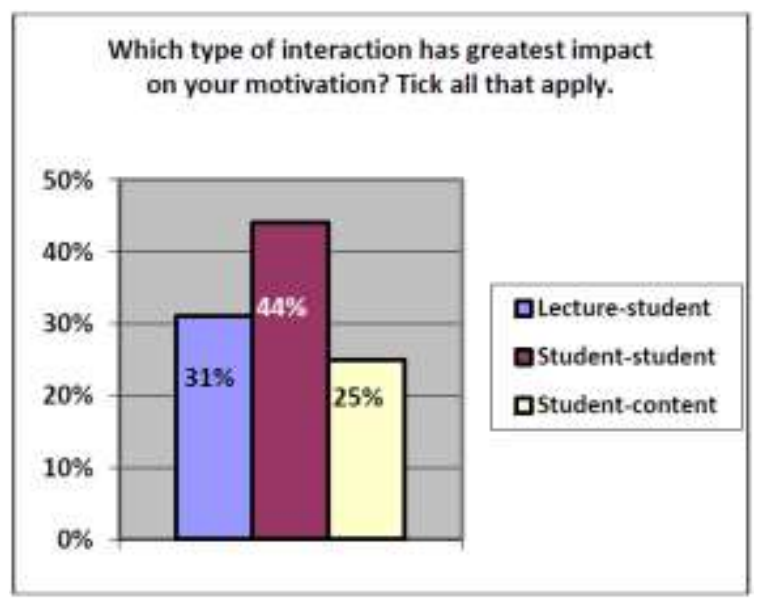

Figure 3. Greatest impact on motivation

Figure 3 breaks the ,interactions ${ }^{\text {ee }}$ results further down to the type of interaction that had greatest impact on the student motivation. The result shows that $44 \%$ of the respondents felt that ,interactions with other studentse mostly affected their motivation in the courses. This was followed by ,interactions with the lecturers ${ }^{\text {ee }}$ with $31 \%$ and ,interactions with the course content ${ }^{\text {ee }}$ with $25 \%$.

[12] and [13] concluded from their respective researches that interactive learning does influence motivation. According to [19] description earlier, the dimensions of motivation seemed to be accounted for one way or another. For example ,choice of task ce $^{\text {e }}$ could be indicated by which interaction is taking place. Are the students involved in the task of discussion or reading the course content only? The „efforte could be indicated by: Are the students 
actively participating by posting messages or being inactive? The statistical results conveying the number of times and also the amount of time the respondents access the Moodle site for classes and self use towards the course could give indication of their ,persistence ${ }^{\text {ee }}$.

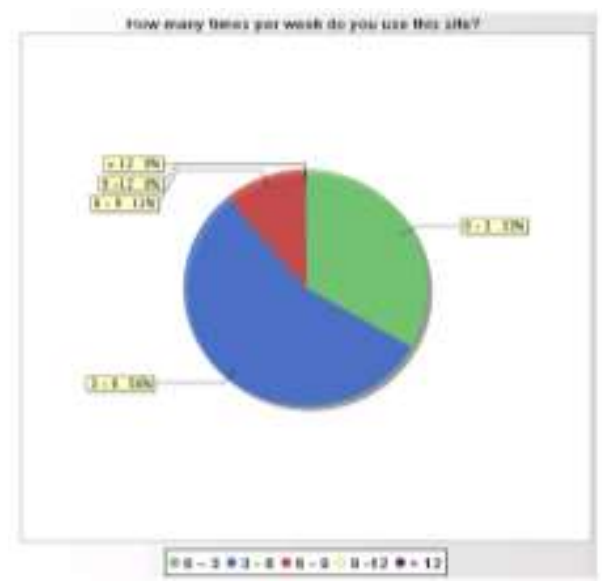

Figure 4. Number of times access Moodle

Figure 4 shows that $56 \%$ of the participants access the Moodle website 3 -6 times a week, and Figure 5 reveals $1 / 3$ of the respondents spend more than $10 \mathrm{hrs}$ on self learning. Does this show an indication of how happy a student uses Moodle site for self-learning outside contact hours?

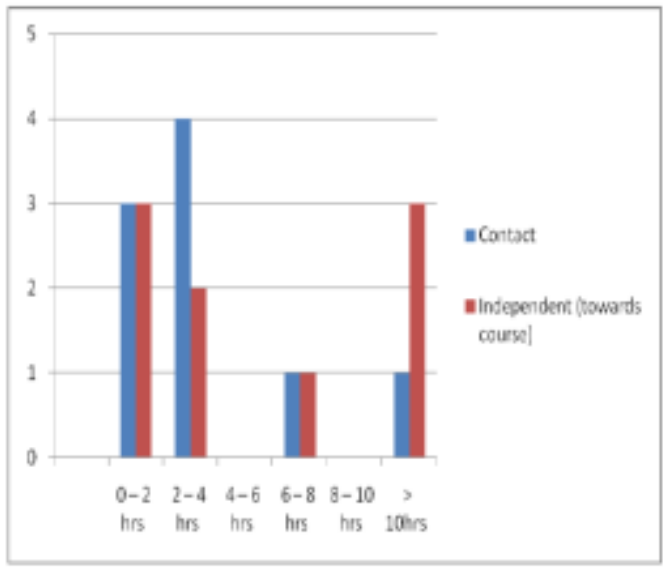

Figure 5. Access hours

It can be argued that the number of times a student spend on self learning or further reads the course content could be an indication of interest.

However, it could also be an indication of the need to read to understand more. For which ever cause, [18] definition of motivation as being ,reasons contributing to an adults decision to engage in learning activities ${ }^{\text {ee }}$ is satisfied, as it is possible that the studentse reasons for many hours of self learning is for the reason of contributing to learning activities.

[3] study of the three types of interactions suggested that the lecturer's input to class interactions plays a very important role in student enthusiasm or motivation. Despite the inferences from Figure 3, Moore's suggestion of the importance of the role of the lecturer is nevertheless supported by the participants' rating of the lecturers' participation in classes with $67 \%$ saying their lecturers were being active in their respective courses compared to $33 \%$ who felt the lecturers were averaged.

Table 1. Student thoughts about Moodle

\begin{tabular}{|l|l|l|l|}
\hline \multicolumn{1}{|c|}{ Thoughts } & Student ID & Age & $\begin{array}{c}\text { Moodle } \\
\text { over F2F? }\end{array}$ \\
\hline $\begin{array}{l}\text { I am really enjoying using } \\
\text { this as a delivery mode as it } \\
\text { is asynchronous and I can } \\
\text { be with my family while I } \\
\text { am engaging in study. I } \\
\text { work full-time+ so I like to } \\
\text { be at home as often as I } \\
\text { can. }\end{array}$ & F1 & 40 - 50 & Yes \\
\hline $\begin{array}{l}\text { Moodle is a great way for } \\
\text { me to complete the paper } \\
\text { because I live in Wellington } \\
\text { and work full time. I like the } \\
\text { asynchronous way I can } \\
\text { engage with the other } \\
\text { participants. }\end{array}$ & F2 & & \\
\hline $\begin{array}{l}\text { Useful tool for external } \\
\text { students- rapid responses } \\
\text { to questions and } \\
\text { discussions }\end{array}$ & F3 & 40 -50 & Yes \\
\hline $\begin{array}{l}\text { This is the first time that I } \\
\text { had to participate in online } \\
\text { classes. Since the beginning } \\
\text { of this year, I have had a lot } \\
\text { of difficulties in adapting to } \\
\text { this new studying style. }\end{array}$ & F4 & & \\
\hline $\begin{array}{l}\text { I am a kinaesthetic learner } \\
\text { therefore, action is very } \\
\text { important to my learning } \\
\text { process. }\end{array}$ & F4 & & \\
\hline $\begin{array}{l}\text { One thing that has helped } \\
\text { me improve my skills was } \\
\text { the lecturer feedback and } \\
\text { encouragement. }\end{array}$ & F4 - & & \\
\hline $\begin{array}{l}\text { I don't think Moodle is used } \\
\text { effectively to really teach } \\
\text { the course. Moodle is just a } \\
\text { place for me to post what I } \\
\text { have learnt. Moodle is not } \\
\text { the real problem. The worst } \\
\text { of all the online learning } \\
\text { spaces I've used. }\end{array}$ & F5 & \\
\hline
\end{tabular}

4.2.1. Why no motivation? The $33 \%$ (see Figure 2) could be further detailed by Table 1 some respondents showed unhappiness for various reasons ranging from the course design and the lecturer not suitable for online mode to having difficulties due to lack of skill in the online learning style. Two particular students indicated they are either only doing the course online because it is not offered face 
to face yet it is a required paper or that they have to work during the day.

Table 2. Student thoughts about Moodle

\begin{tabular}{|c|c|c|c|}
\hline Thoughts & Student ID & Age & $\begin{array}{l}\text { Moodle } \\
\text { over F2F? }\end{array}$ \\
\hline $\begin{array}{l}\text { Online learning tools are so } \\
\text { powerful, but does not } \\
\text { replace or come close to } \\
\text { effectiveness of a real } \\
\text { classroom }\end{array}$ & F5 & & \\
\hline $\begin{array}{l}\text { The lecturers do not know } \\
\text { how to teach in an online } \\
\text { environment }\end{array}$ & F5 & & \\
\hline $\begin{array}{l}\text { The course has not been } \\
\text { designed to facilitate } \\
\text { learning. }\end{array}$ & F5 & & \\
\hline $\begin{array}{l}\text { As we are graded on our } \\
\text { interactions, people do not } \\
\text { write posts about actual } \\
\text { questions or real issues in } \\
\text { case they are given poor } \\
\text { grades for not } \\
\text { demonstrating } \\
\text { understanding. It is such a } \\
\text { fake way to learn. }\end{array}$ & F5 & & \\
\hline $\begin{array}{l}\text { I have taught myself the } \\
\text { material }\end{array}$ & F5 & & \\
\hline $\begin{array}{l}\text { I hate it!!!! Much prefer } \\
\text { face to face lectures, only } \\
\text { using Moodle because I } \\
\text { have to do this paper }\end{array}$ & F6 & $40-50$ & No \\
\hline $\begin{array}{l}\text { will definitely look at } \\
\text { papers for next year and if } \\
\text { they are only offered on } \\
\text { Moodle I will not consider } \\
\text { them }\end{array}$ & F6 & & \\
\hline $\begin{array}{l}\text { It is great that you can } \\
\text { choose the time and day } \\
\text { that suits you the most. It is } \\
\text { very user friendly }\end{array}$ & F7 & $20-30$ & Yes \\
\hline $\begin{array}{l}\text { It is a great medium to } \\
\text { learn in }\end{array}$ & F8 & $>50$ & Yes \\
\hline $\begin{array}{l}\text { Moodle suits my needs as I } \\
\text { am in full time work and } \\
\text { wanted to distance study. } \\
\text { Without it I would have no } \\
\text { time to fit in my studies... }\end{array}$ & M1 & $30-40$ & Yes \\
\hline
\end{tabular}

4.2.2. Why motivation? Table 2 reveals implications of motivation. About $67 \%$ of the participants give indications of being happy and enthusiastic about the courses they were doing using the Moodle environment. These students see Moodle as being a good, user friendly, convenient delivery mode which accommodate distant learners asynchronously and get feedback fast.

\subsection{Interactions affect confidence}

Interaction can imply something about one's confidence. Interaction and confidence simultaneously affect each other. Does interaction elicited via Moodle environment affect the learner's confidence? $78 \%$ of the participants (see Figure 2) believed that interactions using Moodle had improved or improved their confidence in the course a lot. $78 \%$ is a huge amount of percentage compared to those who felt interaction did not have any effect at all or had decreased their confidence with $11 \%$ for each category

Although there were no scientific or statistical recordings to show indication of confidence prior to and after implementation of Moodle for their distant learning, the respondents' own personal answers relay their perceptions and could sufficiently justify their responses. It was the only method implemented in this project to gain some insight into how the interactions over e-learning have impacted on a student's level of confidence in the course.

Table 3. Which interaction has greatest impact?

\begin{tabular}{|l|l|l|l|l|l|l|}
\hline $\begin{array}{l}\text { Type of } \\
\text { interacti } \\
\text { on }\end{array}$ & $\begin{array}{l}\text { Grealest } \\
\text { impact on } \\
\text { Motivatio } \\
\text { n }\end{array}$ & $\begin{array}{l}\text { Greatest } \\
\text { impact on } \\
\text { Confidene } \\
\text { e }\end{array}$ & \multicolumn{3}{|l|}{$\begin{array}{l}\text { Greatest } \\
\text { impact } \\
\text { on }\end{array}$} \\
$\begin{array}{l}\text { Performa } \\
\text { nce }\end{array}$ \\
\hline $\begin{array}{l}\text { Student- } \\
\text { lecture }\end{array}$ & 5 & $31 \%$ & 5 & $38 \%$ & 5 & $43 \%$ \\
\hline $\begin{array}{l}\text { Student- } \\
\text { student }\end{array}$ & 7 & $44 \%$ & 3 & $23 \%$ & 2 & $14 \%$ \\
\hline $\begin{array}{l}\text { Student- } \\
\text { coutent }\end{array}$ & 4 & $25 \%$ & 5 & $38 \%$ & 5 & $43 \%$ \\
\hline
\end{tabular}

It is interesting to notice that there seems to be a relationship between student-lecturer interaction and the student's confidence in the course. The result of one particular student F4 shown in Table 4 shows an ,improvement on interaction with lecture ${ }^{\text {ee }}$ and improvement in confidence ${ }^{e e}$. In comparison, student F6 has ,no effect ${ }^{\text {te }}$ on interaction with the lecturer and „no effecte on confidence whereas student M1 has ,improvement ${ }^{\text {te }}$ on interaction with lecturer and ,improve a lote on confidence in the course.

Table 4. Student answers

\begin{tabular}{|c|c|c|c|}
\hline \multicolumn{4}{|c|}{ How do you think Moodle has affected your... } \\
\hline & $\mathrm{F} 4$ & F6 & MI \\
\hline $\begin{array}{l}\text { Interactions with } \\
\text { lecturer }\end{array}$ & insprove & no effect & improve \\
\hline $\begin{array}{l}\text { Interactions with } \\
\text { other students }\end{array}$ & decrease & no effeet & $\begin{array}{l}\text { improve } \\
\text { a lot }\end{array}$ \\
\hline $\begin{array}{l}\text { Access to course } \\
\text { content }\end{array}$ & $\begin{array}{l}\text { no } \\
\text { efteet }\end{array}$ & improve & $\begin{array}{l}\text { improve } \\
\text { a lot }\end{array}$ \\
\hline \multicolumn{4}{|c|}{ How do you think Interactions affected your... } \\
\hline Motivation & $\begin{array}{l}\text { decrease } \\
\text { a lot }\end{array}$ & no effect & improve \\
\hline $\begin{array}{l}\text { Confidence in the } \\
\text { course }\end{array}$ & ingroye & no effect & $\begin{array}{l}\text { improve } \\
\text { a lot }\end{array}$ \\
\hline Performance & decrease & no effect & improve \\
\hline
\end{tabular}




\subsection{Interactions affect performance}

In this study, performance is not quantitatively measured by any record of marks but again is based on the respondent's self-reports on their own performances. Has the respondent's performance decreased, decreased a lot, no effect, increased or increased a lot while Moodle is being used to facilitate interactions? Figure 4.2 shows $67 \%$ of the respondents felt that the interactions on e-learning had improved their performance. The other $33 \%$ were for no effect and decrease performance.

4.4.1. What type of interaction? It is quite interesting to notice from the responses (see Table 3) that $43 \%$ of students felt that the student-lecturer and equally the student-content types of interactions had greatest impact on their performances. It is also quite interesting to note that for motivation, studentstudent interactions are the most important (Figure 3). However, for performance, student-student interactions are the least important.

4.4.2. What do these results suggest? The results suggested the importance of the student-lecturer interaction and the student-content interactions on performance. While the student does his/her part, the role of the lecturer should not be undervalued; feedback must be personalised, purposeful and prompt [13]. The student will need to know if $s /$ he is on the correct path of thinking towards a topic discussed. The student needs some encouragement so that $\mathrm{s} / \mathrm{he}$ will have the urge to participate more in class discussions. $45 \%$ of the students as displayed in Figure 6 felt that active participation from the lecturer is good because lecturers have more knowledge of the topics discussed and they therefore ask challenging questions to keep the discussion going. The challenging questions from the lecturers can direct the students to the correct thinking path. As well as that, the students also think by active participation from the lecturer, the lecturer is modelling the use of the on-line space. "Student-toinstructor interactions are the instructor's efforts to stimulate learner interest and motivation, to assist students in organizing information in order to apply what they have learned, and to provide evaluation and feedback to the learner on progress" [16]. This type of interaction is important in responding to the learners' application of new knowledge". Referring back to Student F4 in Table 4.3, the student felt her performance had ,_decreased ${ }^{e e}$, yet her interactions with the lecturer improved. Her feedback in Table 1 indicates her inexperience in the on-line learning style and she acknowledges the lecturer's feedback and encouragement to have helped her. This supports the crucial part of the lecturer on this particular student's learning.
"Students who had higher perceived levels of interaction with teachers had higher perceived levels of satisfaction with the course and reported higher levels of learning" [14]. Swan suggested that the teachers must induce quality interactions, which interactions occur by ,posting regularly, responding in a timely manner and modelling good online communication and interaction ${ }^{e e}$. The conclusions formed by these researchers are supported by the respondents to the present study, who felt that the teacher's participation is important because the students need to 1) get feedback, 2) encouragement 3 ) teachers must learn about their students 4) it is their job and 5) other reasons as stated in Figure 6.

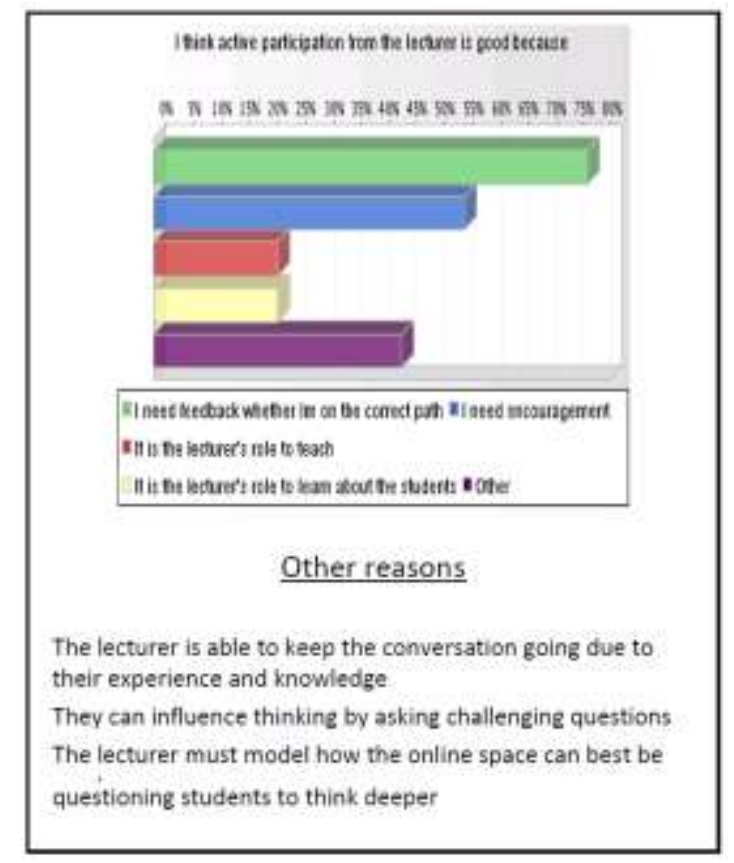

Figure 6. Lecturer active participation

In addition to the lecturer participation, the student-content interactions (43\%) have high impact on the students' performance. Again by looking at certain interesting cases, while M1 has improved a lot on interaction with content, his performance also improved and F4 who had no effect on interaction with content had decreased performance. It can be assumed however, from the personal opinions that F4's inexperience in the on-line learning style had something to do with her lack of interaction with the content and decrease performance. It can be assumed F4 is comparing how she performed in e-learning with her previous face-to-face learning experience.

It is valid to point out that only $14 \%$ students thought student-student interaction had greatly impacted on their performance. It can only be assumed that not all student-student interactions would be directly relevant to the discussion. There could be social comments as well as constructive 
focused comments. However, it can be argued that the student-student interaction can give a lead to further reading (student-content). The discussion enables the student to say their views based on information from readings, hence stating the sources.

The rest of the class are bound to look up these links or sources for confirmation. The students in this regard are doing the student-content interaction which can greatly influence their performance.

Although the student response rate of $15 \%$ was quite low, the results still showed some trends. It showed some relationships between student-content interaction and student-lecturer interaction and the student's performance. The more time the student reads lecture notes and messages posted during discussions and accesses the links given for additional information, the more knowledge can be acquired which can reflect on the student's performance. The more feedback and input from the lecturer the better performance.

\subsection{What the lecturer says}

Only one lecturer questionnaire was returned. It was a very short questionnaire and the most important information is displayed below.

Contact class hrs $=2(\max$ per week $)$,

Non contact (towards class) $=4$ (max per week).

Table 5. Lecturer answers

\begin{tabular}{|c|c|c|c|c|c|}
\hline \multicolumn{6}{|c|}{$\begin{array}{l}\text { 6. For class interactions and messaging, how } \\
\text { do you participate? }\end{array}$} \\
\hline \multicolumn{2}{|l|}{ F } & \multicolumn{4}{|c|}{ initiate discussion } \\
\hline \multicolumn{6}{|c|}{$\begin{array}{l}\text { 9. Please use your collective thoughts } \\
\text { regarding the whole class. Rate how you think } \\
\text { Moodle affected factors below }\end{array}$} \\
\hline & $\begin{array}{l}\text { 1: } \\
\text { decr } \\
\text { ease } \\
\text { a lot }\end{array}$ & $\begin{array}{l}2 \\
\text { decr } \\
\text { ease }\end{array}$ & $\begin{array}{l}\text { 3: no } \\
\text { effec } \\
t\end{array}$ & $\begin{array}{l}4 . \\
\text { impr } \\
\text { ove }\end{array}$ & $\begin{array}{l}5: \\
\text { improv } \\
\text { ea lot }\end{array}$ \\
\hline $\begin{array}{l}\text { Shudent } \\
\text { interactions } \\
\text { with lecturer } \\
\text { ou) }\end{array}$ & $r$ & $\mathrm{C}$ & $\mathrm{r}$ & $\bullet$ & 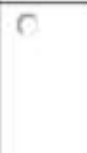 \\
\hline $\begin{array}{l}\text { Shudent } \\
\text { confidence } \\
\text { in the course }\end{array}$ & $r$ & r. & $r$ & $\bullet$ & C \\
\hline \multicolumn{6}{|c|}{$\begin{array}{l}\text { 12. Please state your overall thoughts about } \\
\text { Moodle }\end{array}$} \\
\hline \multicolumn{6}{|c|}{$\begin{array}{l}\text { Used to teach the course in a face to face mode } \\
\text { however, moch prefer the flexibility of moodle } \\
\text { and the emphasis that it places on the post grad } \\
\text { student to research, grow and develop ete }\end{array}$} \\
\hline
\end{tabular}
the lecturer answers supported what the students said. The lecturer responses supplied can be evaluated to support (67\%, see Figure 2) that the overall student confidence in the course have improved. The lecturer also supported that studentlecturer interactions have improved (78\%, see Figure 1). The case study however conveyed some contradiction. The lecturer seemed to be not interactive at all but just initiated the discussion, yet it is said the student-lecturer interaction has improved (see Table 5).

It also showed in the overall thoughts (q 12) that "emphasis is placed on the post graduate students to research, grow and develop". These results seemed to suggest that the weight of e-learning was on the students.

\subsection{Other findings}

A trend is inferred which might be related to the respondents' ages. Apparently, matured students 40 - 50yrs old and above tended to be showing more enthusiasm in doing the course online. A ratio of $4: 1$ reflects four liked the course and one did not. For the young adults there was no real significance showing. Two people 20 - 30 and 30 - 40yrs also enjoyed the course and how it was being offered while the other two showed concerns.

Some issues identified were the learning styles, the design of the course, the type of lecturer and type of learner. According to a student's comments, there could be an issue where the students were graded on making postings irrespective of whether they were valuable questions or addressing real issues. Benefits of e-learning have also been identified. These are mostly to do with flexibility, convenience, accessibility and feedback.

Asynchronous learning is the most appropriate mode of learning for distant learners. It can be assumed that availability of materials online any time could have increased their time on a task like reading and engaging in discussions. Fast feedback was identified as a benefit of online interactions either from the lecturer or from other students.

\section{Conclusions}

The research problem was to find out if the Moodle learning environment affected interactions and if these student-lecturer, student-student and student-content interactions have impact on the student's „motivation ${ }^{\text {ee }}$ „,confidence ${ }^{\text {ee }}$ and „performance ee. Overall, according to student perceptions, the use of Moodle improved all the three types of interactions. The results suggested that the higher the interaction the higher the students rated their motivation, confidence or performance comparing how they were near the beginning of the 
course to how they were later on in the course. Some interesting patterns were found. The student-lecturer interactions and student-content interactions give a general equivalency of impact across the students' motivation, confidence and performance. The results suggested that where the students rated the lecturer as being active, there was high impact on confidence and performance and where the lecturer was rated average, there was low impact on student confidence and performance. The student-student interaction on the other hand was found to have the greatest impact on motivation.

Although the participant's skills, knowledge and background were assumed to be not important in this research, the results once again revealed the contribution of these variables to the learners in the context of learning. The course design, e-learning style and type of lecturer seemed to be affecting a minority of students' learning experiences and the interactions that take place. The use of Moodle for elearning and interactions seemed to be working quite well for the learners who were distant and working and experienced in the e-learning mode of study.

It can be concluded that the shift of pedagogy learning from classroom to e-learning shifted the emphasis on the learner to adapt to new learning styles, manage their time, develop and use research skills and think constructively regarding lecturer and fellow students comments. It can be concluded that the matured learners seemed to appreciate this elearning style more due to their working lifestyle.

\section{Recommendations}

It is recommended that more future research should be done on the use of Moodle for interactions using either learner perceptions or real scientific recordings. For the qualitative methodology, it would be better to do both the survey questionnaire and interviews for selected case studies, (picked from respondents) to explore more on any issue of interest shown in the questionnaire responses. For a quantitative methodology, real records of academic results recorded near the beginning of the course and towards the end of the course could make a realistic comparison. Implement a web-based interface system like [17] to record the weighting of postings made per person, or apply the functionality that is already available in Moodle. The postings should be read by the lecturer to check on relevancy instead of grading students on the weighting only. E-learning is ubiquitous and teaching and learning culture and environments are changing. Moodle as a LMS is rising in number of users, sites and courses each month. The students should take advantage of the options that accommodate their lifestyle better especially if they are working. The lecturers are recommended to check out if their courses are designed to go online. The lecturers are encouraged to find out how the students feel and to identify gaps to bridge in order to take full advantage of e-learning opportunities and to reach out to hundreds of students at a distance. Although the emphasis is shifted to encouraging students to develop and use research skills and to manage time appropriately, it is worthy to re-evaluate the course design, the lecturer as well as the student capabilities. Any opportunity to enhance teaching and learning should be used. Lecturers and students are recommended to answer surveys relevant which could further develop and enhance the learning processes for the betterment of education. For the variables; the sample size should be big enough to derive significance. The course should be justified to be offered online. It is essential that the students and the lecturers using any LMS should be trained on using the LMS before doing the course. Because it is not justifiable to compare two different courses as each course has its own type of content and level of difficulty, it is recommended to use one same course for an evaluation. The course must also be taught by one same lecturer as again different lecturers have different capabilities and personalities. Finally the participants being surveyed should be clear on whether they are comparing Moodle to another LMS or comparing the use of Moodle being an e-learning environment to a faceto-face mode, or evaluating the effects of Moodle itself during a course of study.

\section{References}

[1] P Henry E-learning technology, content and services. Education and Training, Vol 43, pp 249 - 255, 2001 [Online]. Available: http://moodle.org/stats/ (Access Date: 4 October, 2009)

[2] A. Parker, Interaction in Distance Education: The Critical Conversation, Educational Technology Review, 1999. (Access Date: 15 August, 2009)

[3] M. Moore, Three types of interaction, The American Journal of Distance Education, (1992). (Access Date: 15 August, 2009)

[4] http://en.wikipedia.org/wiki/Confidence, (Access Date: 26 September, 2009)

[5] P., D. Leedy, \&, J., E. Ormrod, Practical Research: Planning and Design 8th edn, Pearson Prentice Hall, New Jersey, 2005.

[6] N. Sclater, Enhancing Moodle to meet the needs of 200,000 distance learners. In: Silesian Moodle Moot, 3031 Oct 2008, Technical University of Ostrava, Celadná, Czech Republic , 2008. Available: http://oro.open.ac.uk/15 283/1/Niall_Sclater_SMM.pdf (Access Date: 10 May, 2009).

[7] A. Berggren et al., Practical and Pedagogical Issues for Teacher adoption of IMS Learning Design standards in Moodle LMS, JIME: Learning Design Standards in 
Moodle, 2005. http://jime.open.ac.uk/20058/02/berggren2005-02-paper.html. (Access Date: 26 September, 2009)

[8] W. Torbacki, Achievements in Materials and Manufacturing Engineering, Vol 22 Issue 1, May, 2007,pg 93

[9] http://moodle.org/stats/, (Access Date: 26 September, 2009)

[10] A. P. Rovai, \& K.T. Barnum, Online course Effectiveness: An analysis of Student Interactions and Perceptions of Learning, Journal of Distance Education, Vol 18 No: 157 -73, 2003.

[11] J. B. Strother, An Assessment of the Effectiveness of e-learning in Corporate Training Programs. The International Review Of Research In Open And Distance Learning, Vol 3 No 1 (2002) [Online] Available: http://www.irrodl.org/index.php/irrodl/article/view/83/160 (Access Date: 26 September, 2009)

[12] L. Schaffer \& D. Hannafin, The effects of progressive interactivity on learning from interactive video, Educational Communication and Technology Journal, 1993.

[13] B. Ussher, (nod), Interactions, Student Enthusiasm and Perceived Learning In An Online Teacher Education Degree. (Access Date: 14 August, 2009)

[14] K. Swan, Virtual Interaction Design factors Affecting Student Satisfaction and Perceived Learning In Asynchronous On-line Courses, Distance Education v22 n2, pg 306-331, 2001.

[15] J. Merisotis \& R. Phipps, What's the Difference: A Review of Contemporary Researh on the Effectiveness of Distance Learning in Higher Education, Journal of Distance Education, Vol 14 No 1, 102-114, Spring/Printemps, 1999. (Access Date: 14 August, 2009)

[16] M. Moore and G. Kearsley, Distance education: A systems view, Belmont, CA: Wadsworth, 1996.

[17] A.R. Figueira \& J.B Laranjeiro, Interaction visualisation in Web-Based Learning using iGraphs, September 10 -12, Manchester, UK, 2007,

[18] M. G. Moore \& W. G. Anderson (Eds), Handbook of Distance Education, Mahwah, NJ: Lawrence Eflbaum, 2003

[19] R. Pintrich, Motivation in Education: Theory, Research and Applications, Merrill, 1996 